\title{
PERTANGGUNGJAWABAN PIDANA PERAMPASAN ASET HASIL TINDAK PIDANA KORUPSI SEBAGAI SALAH SATU WUJUD PELAKSANAAN KEADILAN RESTORATIF (RESTORATIVE JUSTICE)
}

\author{
Yogi Yasa Wedha ${ }^{(1)}$, I Made Wirya Darma ${ }^{(2)}$ \\ yogiardin@gmail.com ${ }^{(1)}$, dedukdd81@gmail.com ${ }^{(2)}$
}

\section{Undiknas Graduate School}

\begin{abstract}
This research raises the problem of criminal liability for the seizure of assets resulting from criminal acts of corruption. Whereas the legal instrument for asset deprivation used in Indonesia is now based on the criminal law code (KUHP) and the Corruption Eradication Act (UU PTPK) which in fact has not been effective in returning state losses due to corruption. The author sees no blurring norms where there are still many weaknesses that must be corrected in accordance with the paradigm that developed currently is restorative justice. The formulation of the problem in this research is (1). What is the regulation of criminal liability for the appropriation of assets from corruption in Indonesia currently? (2). How does criminal liability account for the appropriation of assets resulting from corruption in accordance with restorative justice thinking? This type of research is normative research or literature research, namely legal research conducted by researching library materials (library research), with the approach of legislation, concept approach and analytical approach. The legal theory used is criminal responsibility theory that is related to proportionality in the desert theory of Andrew Von Hirsch and Andrew Asworth and Theory of justice from John Rawls. The results of this study indicate that the construction of criminal liability for the disposal of corruption assets is placed as an additional facultative and complementary criminal, it does not effectively restore the losses of the State resulting in injustice. The conclusion of this research is that there must be a change of retributive criminal responsibility paradigm towards a restorative paradigm that is oriented towards the recovery of loss and suffering experienced by the State / society. To the authors provide suggestions for asset deprivation is placed as the principal and related institutions immediately drafted the Law on the appropriation of proceeds of crime
\end{abstract}

Keywords: Asset deprivation, Corruption, Restorative Justice.

\begin{abstract}
ABSTRAK
Penelitian ini mengangkat masalah pertanggungjawaban pidana perampasan aset hasil tindak pidana korupsi. Bahwa instrumen hukum perampasan aset yang digunakan di Indonesia saat ini berlandaskan kitab undang undang hukum pidana (KUHP) dan Undang-undang pemberantasan tindak pidana korupsi (UU PTPK) yang secara faktual belum efektif mengembalikan kerugian negara akibat tindak pidana korupsi. Penulis melihat ada norma kabur dimana masih banyak kelemahan yang harus diperbaiki disesuaikan dengan paradigma yang berkembang saat ini yaitu restorative justice. Rumusan masalah dalam Penelitian ini adalah (1). Bagaimanakah pengaturan pertanggungjawaban pidana perampasan aset hasil tindak pidana korupsi di Indonesia saat ini? (2). Bagaimanakah mewujudkan pertanggungjawaban pidana perampasan aset hasil tindak pidana korupsi yang sesuai dengan pemikiran keadilan restoratif ? Jenis
\end{abstract}


penelitan ini adalah penelitian normatif atau penelitian hukum kepustakaan, yaitu penelitian hukum yang dilakukan dengan cara meneliti bahan pustaka (library research), dengan pendekatan peraturan perundang undangan, pendekatan konsep dan pendekatan analisis. Teori hukum yang digunakan adalah teori pertangungjawaban pidana yaitu terkait dengan proporsionalitas dalam pemidanaan (desert theory) dari Andrew Von Hirsch dan Andrew Asworth dan teori keadilan (Theory of justice) dari John Rawls. Hasil penelitian ini menunjukkan bahwa konstruksi pertanggungawaban pidana permpasan aset tindak pidana korupsi ditempatkan sebagai pidana tambahan yang bersifat fakultatif dan komplementer, tidak efektif mengembalikan kerugian Negara sehingga menimbulkan ketidakadilan. Kesimpulan penelitian ini adalah harus ada perubahan paradigma pertanggungjawaban pidana yg sebelumnya bersifat retributif menuju pada paradigma restoratif yang berorientasi pada pemulihan kerugian dan penderitaan yang dialami Negara//masyarakat. Untuk itu penulis memberikan saran agar perampasan aset ditempatkan sebagai pidana pokok dan lembaga terkait segera menyusun UndangUndang tentang perampasan aset hasil tindak pidana

Kata Kunci: Perampasan aset, Korupsi, Keadilan restoratif / restorative justice.

\section{PENDAHULUAN}

Praktek korupsi terjadi hampir disetiap lapisan birokrasi, baik legislatif, eksekutif, maupun yudikatif, bahkan telah menjalar ke dunia usaha, ibarat penyakit, korupsi merupakan penyakit yang sudah kronis, sehingga sulit untuk penyembuhannya. Dalam konsideran Undang-Undang No. 31 tahun 1999 (UU 31/1999) jo Undang- Undang No. 20 tahun 2001 (UU 20/2001) tentang Pemberantasan Tindak Pidana Korupsi, bahwa korupsi terjadi secara sistematis dan meluas merupakan pelanggaran terhadap hak-hak sosial dan hak-hak ekonomi masyarakat, sehingga korupsi telah digolongkan sebagai kejahatan luar biasa (extra-ordinary crime), untuk itu pemberantasannya harus dilakukan dengan cara-cara yang luar biasa ${ }^{1}$.

Transparansi Internasional Indonesia menyatakan bahwa tahun 2016 korupsi di Indonesia menempati urutan ke -90 dari 176 Negara diukur di dunia ${ }^{2}$. Data ini menunjukkan bahwa pemberantasan korupsi selama ini

${ }^{1}$ Rolas Jakson,2015, Korupsi Merupakan Extra Ordinary Crime, available at: http://www.kompasiana.com/www.rolastampubolon.wordpress.com/korupsimerupakan-extra- ordinary-crime_552c09f76ea8341e2f8b458, diakses pada tanggal 20 Desember, 2017.

${ }^{2}$ BBC Indonesia, 2017, Indek Persepsi Korupsi Indonesia Disebut Membaik tapi lamban, available at http://www.bbc.com/indonesia/indonesia- 
tidak mengalami kenaikan yang signifikan. Jumlah kerugian negara yang berhasil diselamatkan hanya sepuluh persen dari kerugian negara akibat tindak pidana korupsi ${ }^{3}$. Hal ini menandakan bahwa kegiatan pengembalian kerugian negara masih belum berjalan secara optimal. Korupsi merupakan perbuatan melawan hukum tidak hanya melanggar undang-undang, juga melanggar terhadap hak orang lain terutama pelanggaran terhadap kepentingan masyarakat yang harus dipertanggungjawabkan.

Sikap berani Pemerintah Indonesia dalam memberantas tindak pidana korupsi dan pengembalian kerugian negara harus konsisten dan realistis, melakukan penataan terhadap sistem hukum di Indonesia termasuk menata struktur dan lembaga-lembaga hukum yang ada, penataan substansi hukum dengan mengkaji kembali aturan-aturan yang ada dan melakukan revokasi (penarikan kembali), revisi (pengubahan) serta pemberlakuan ketentuan baru yang diperlukan dan budaya hukum yang hidup (living law) yang dianut dalam suatu masyarakat ${ }^{4}$

Paradigma Pemidanaan dalam KUHP dan UU PTPK menganut paradigma retributive yaitu penegakan hukum yang lebih menekankan pada penjatuhan hukuman terhadap pelaku, faktannya paradigma retibutif ini tidak dapat memenuhi tujuannya dalam memberikan efek jera kepada pelaku tindak pidana, dan belum mampu memulihkan penderitaan yang dialami korban dalam hal ini kerugian Negara dan masyarakat. Kondisi ini memunculkan gagasan baru tentang sistem pemidanaan yang berorientasi upaya pemulihan kerugian dan penderitaan yang dialami korban yang dikenal dengan pendekatan restorative justice. Rumusan masalah yang akan dibahas dalam tulisan ini adalah mengenai konstruksi hukum pertanggungjawaban perampasan harta hasil tindak pidana korupsi sebagai wujud pelaksanaan keadilan restoratif.

38734494, diakses pada 23 Pebruari 2018.

${ }^{3}$ Ruli, 2016, ICW:Tahun 2015, Kerugian Negara Akibat Korupsi Rp31,077 Triliun Available at

http://nasional.harianterbit.com/nasional/2016/02/24/57464/44/25/ ICW-Tahun2015- kerugian- Negara-Akibat-Korupsi-Rp31077-Triliun. Diakses pada tanggal 16 Desember 2017.

${ }^{4}$ Putriyana Nia dan Shintiya Dwi Puspita, 2014, TanggungJawab Hukum Dalam Konteks Perbuatan Melawan Hukum Terhadap Tindak Pidana Korupsi, Jurnal Arena Hukum, Vol 7, No 3. Universitas Katolik Parahyangan Bandung, h. h.3. Available at http://arenahukum.ub.ac.id/index.php/arena/article/view/173, diakses pada tanggal 16 Desember 2017. 


\section{II . TINJAUAN PUSTAKA}

Asas hukum yang berkaitan dengan penelitian ini adalah asas legalitas (nullum delictum nulla poena sine praevia lege poenali) dan asas tiada pidana tanpa kesalahan. (geen straft zonder schuld); Setiap orang yang dijatuhi pidana harus terbukti melakukan suatu kesalahan berdasarkan peraturan yang berlaku sehingga penjatuhan pidana dapat secara proporsional diterapkan sesuai dengan kesalahannya.

Pertanggungjawaban adalah suatu perbuatan yang tercela oleh masyarakat dan dipertanggungjawabkan pada si pembuatnya. Untuk adanya pertanggungjawaban pidana harus jelas terlebih dahulu siapa yang dapat dipertanggungjawabkan, ini berarti harus dipastikan terlebih dahulu yang dinyatakan sebagai pembuat suatu tindak pidana ${ }^{5}$. Menurut Roeslan Saleh, pertanggungjawaban pidana merupakan sesuatu yang dipertanggungjawabkan secara pidana terhadap seseorang yang melakukan tindak pidana ${ }^{6}$.

Tindak pidana korupsi adalah perbuatan yang melanggar hukum pidana yang berhubungan dengan perbuatan busuk, tidak jujur, dapat disuap. Kata korupsi dipergunakan sebagai suatu acuan untuk serangkaian tindakan terlarang atau melawan hukum secara luas ${ }^{7}$. Perilaku korupsi secara umum merujuk pada perbuatan menyalahgunakan kekuasaan atau jabatan publik untuk mendapat keuntungan pribadi. Sedangkan UU PTPK menjelaskan korupsi adalah usaha memperkaya diri sendiri atau orang lain atau suatu korporasi dengan cara penyalahgunaan wewenang dan atau melawan hukum yang akibat tindakannya menyebabkan terjadinya kerugian negara.

Saat ini telah berkembang pendekatan sistem pemidanaan yang menitik beratkan pada adanya partisipasi langsung pelaku, korban dan masyarakat dalam proses penyelesaian perkara pidana yang dikenal dengan restorative justice. Dari berbagai pandangan pakar hukum pada

5 Roeslan Saleh, 1990, Perbuatan Pidana dan Pertanggungjawaban Pidana, Aksara Baru, Jakarta, h. 80.

${ }^{6}$ Ibid. h. 75.

7 Andrian Suted, 2009, Aspek Hukum Barang dan Jasa dan Berbagai Permasalahannya, Sinar Grafika, Jakarta, h. 80. 
prinsipnya restorative justice mengandung makna yaitu suatu konsep pemikiran yang terkait dengan sistem pemidanaan yang tidak hanya menitik beratkan pada kebutuhan dan penjatuhan hukuman terhadap pelaku, tetapi juga memperhatikan dan melibatkan korban dan komunitasnya (masyarakat) yang dirasa tersisih dengan mekanisme kerja sistim peradilan pidana yang berlaku saat ini ${ }^{8}$.

Pelaku tindak pidana korupsi mengambil kekayaan atau kesempatan yang seharusnya dapat dipergunakan untuk memakmurkan kehidupan rakyat ${ }^{9}$. Tindakan pengembalian aset hasil tindak pidana korupsi juga merupakan pengobatan atas pencorengan terhadap keadilan sosial ${ }^{10}$. Bahwa pelaku tindak pidana korupsi harus bertanggungjawab atas kerugian yang diderita oleh Bangsa Indonesia. Wright 1991, dikutip oleh Rufinus hotmaulana, mengatakan tujuan utama dari keadilan restoratif adalah pemulihan, sedangkan tujuan kedua adalah ganti rugi ${ }^{11}$.

Sebagi pisau analisis, dalam penelitian ini menggunakan teori pertanggungjawaban hukum dan teori keadilan. Teori pertanggungjawaban dikemukakan oleh Andrew Von Hirsch dan Andrew Asworth, mengemukakan Desert Theory tentang proporsionalitas dalam pemidanaan yang mensyaratkan adanya perimbangan antara kesalahan dan hukuman. Teori pertanggungjawaban merupakan teori yang menganalisis tentang tanggung jawab subyek hukum atau pelaku yang telah melakukan perbuatan melawan hukum atau perbuatan pidana sehingga menimbulkan kerugian ${ }^{12}$. Teori ini mengkaji dan menganalisis tentang kesediaan dari pelaku tindak pidana untuk memikul biaya atau

${ }^{8}$ Bambang Waluyo, 2016, Penegakan hukum di Indonesia, Sinar Grafika Jakarta, h. 108.

${ }^{9}$ Arya Maheka, Mengenal dan Memberantas Korupsi, Penerbit Komisi Pemberantasan Korupsi, Jakarta. h. 5

${ }^{10}$ M.Purwaning Yanwar, 2007, Pengembalian Aset Hasil Korupsi: Berdasarkan Konvensi PBB Anti Korupsi Dalam Sistem Hukum Indonesia, PT.Alumni, Bandung, h. 63.

11 Rufinus Hotmaulana Hutahuruk, 2006, Penanggulangan Kejahatan Korporasi Melalui Pendekatan Restoratif Suatu Terobosan Hukum Edisi 1, Sinar Grafika, Jakarta. h 107.

12 H. Salim HS. Dan Erlies Septiana Nurbani, 2015, Penerapan Teori Hukum Pada Penelitian dan Tesis (Buku Kedua), Cetakan Kedua, PT. Raja Grafindo Persada, Jakarta,h. 207. 
kerugian atau melaksanakan pidana atas kesalahan maupun kealpaan ${ }^{13}$. Dengan demikian pertanggungjawaban pidana merupakan bentuk perbuatan yang dibebankan kepada pelaku tindak pidana terhadap kesalahan yang dilakukannya. Pertanggungjawaban pidana terjadi karena ada perbuatan yang merupakan tindak pidana, dilakukan oleh seseorang, dan unsur tindak pidana tersebut telah ada aturan yang mengaturnya ${ }^{14}$.

Teori keadilan (Theory of justice) mengkaji dan menganalisis tentang keadilan, adil dapat diartikan dapat diterima secara objektif, keadilan dimaknai sifat (perlakuan dan perbuatan) adil diartikan dengan: a.tidak berat sebelah atau tidak memihak;b. berpihak pada kebenaran; c. sepatutnya atau tidak sewenang wenang ${ }^{15}$. John Rawls, merumuskan kedua prinsip keadilan sebagai berikut: 1. Bahwa setiap orang harus memiliki hak yang sama atas kebebasan dasar yang paling luas, seluas kebebasan yang sama bagi semua orang; 2. Ketidaksamaan sosial ekonomi harus diatur sedemikian rupa sehingga (a) diharapkan memberi keuntungan bagi bagi orang-orang yang paling tidak beruntung, dan (b) semua posisi dan jabatan terbuka bagi semua orang ${ }^{16}$.

\section{Metode Penelitian}

Penelitian ini merupakan penelitian hukum normatif atau penelitian hukum kepustakaan, yaitu penelitian hukum yang dilakukan dengan meneliti bahan pustaka ${ }^{17}$. Diperlukan bahan hukum untuk kedalaman analisis dan argumentasi hukum ${ }^{18}$. Penelitian ini menitikberatkan pada studi kepustakaan atau disebut juga sebagai

${ }^{13}$ Op.cit. h. 208

${ }^{14}$ IrwanYulianto,2016, Kejahatan percobaan Pembunuhan Dalam hukum Pidana, Jurnal IImiah Fenomena Volume XIV Nomor 2 November 2016, https://Jurnal .unars.ac.id .

${ }^{15}$ H. Salim HS dan Erlies Septiana Nurbani, Loc.cit, h. 25.

16 Tanya, Bernard L, dkk, 2013 Teori Hukum Strategi Tertib Manusia Lintas Ruang Dan Generasi, Cetakan IV Edisi Revisi, Genta Publishing, Jogyakarta, h. 86.

17 Soerjono Soekanto dan Sri Mamudji, 2011, Penelitian Hukum Normatif, Rajawali Pers, Jakarta, h. 13-14.

${ }^{18}$ Pasek Diantha I Made,2016, Metode Penelitian Hukum Normatif Dalam Justifikasi Teori Hukum Cetakan ke-1, Prenada Media Group, Jakarta, h.141. 
penelitian kepustakaan (library research) yang berdasar pada bahan hukum sekunder ${ }^{19}$.

Dalam penelusuran bahan hukum, dilakukan dengan pendekatan perundang-undangan (Statute approach) yaitu mencari Peraturan Perundang-undangan yang terkait dengan issu. Pendekatan konsep dilakukan dengan penelusuran buku-buku hukum dengan metode snowball theory, untuk menunjang konsep tersebut penulis melakukan pendekatan komparatif dengan Negara lain mengenai isu hukum yang hendak dipecahkan ${ }^{20}$.

Jenis pendekatan dilakukan dengan pendekatan deskriptif , pendekatan Undang Undang (Statute Approach), pendekatan analisis konsep (Analytical \& Conseptual Approach) dan metode perbandingan (Comparative Method). Pokok kajiannya adalah terkait dengan norma hukum perampasan aset hasil tindak pidana korupsi persesuaiannya dengan prinsip keadilan restoratif yang berkembang saat ini.

Untuk menganalisis bahan - bahan hukum yang telah terkumpul digunakan berbagai teknik analisis sebagai berikut; teknik deskripsi; teknik evaluative, proposisi, rumusan norma, keputusan, baik dalam bahan primer maupun dalam bahan hukum sekunder;

Pengolahan dan analisa bahan hukum didahului dengan melakukan pemaparan tentang landasan hukum bagi pelaksanaan perampasan harta hasil tindak pidana korupsi di Indonesia persesuaiannya dengan konsep keadilan restoratif, selanjutnya melakukan evaluasi terhadap landasan hukum yang saat ini digunakan sekaligus juga membandingkan pelaksanaannya dinegara lain. Dari hasil pemaparan, evaluasi dan perbandingan landasan hukum pelaksanaan perampasan harta hasil tindak pidana korupsi tersebut maka penulisakan melakukan teknik argumentasi yaitu penalaran atau reasoning atau penjelasan yang masuk akal.

19 Soerjono Soekanto. Op.cit. h. 195-196.

${ }^{20}$ Ibid. h. 239 


\section{Kerangka Pemikiran}

\begin{tabular}{|c|c|c|c|}
\hline \multicolumn{4}{|c|}{$\begin{array}{l}\text { Pertanggungjawaban Pidana Perampasan Aset Hasil Tindak Pidana Korupsi Sebagai Salah Satu Wujud } \\
\qquad \text { Pelaksanaan Keadilan Restoratif (Restorative Justice) }\end{array}$} \\
\hline I & I & I & I \\
\hline $\begin{array}{l}\text { LATAR BEAKANG } \\
\text { MASALAH }\end{array}$ & RUMUSAN MASALAH & TELAAHPUSTAKA & METODEPENELITIAN \\
\hline $\begin{array}{l}\text { 1. Bahwa Korupsi sebagai } \\
\text { ektra orinary crime, } \\
\text { merusaknilai keadilan } \\
\text { dalam masyarakat, Harus } \\
\text { dipertanggungjawabkan } \\
\text { 2. Bahwa Peraturan } \\
\text { terhadap perampasan } \\
\text { harta hasil tindak pidana } \\
\text { tidak dapat bekerja efektif } \\
\text { karena berbagai kendala } \\
\text { 3. Perubahan paradigma } \\
\text { dari Retributif menjadi } \\
\text { paradigma Restoratif }\end{array}$ & $\begin{array}{l}\text { 1. } \\
\text { pengaimanakah } \\
\text { pertanggungawaban } \\
\text { pidana perampasan } \\
\text { aset hasil tindak } \\
\text { pidana korupsi di } \\
\text { Indonesia saat ini } \\
\text { 2. } \text { Bagaimanakah } \\
\text { mewujudkan } \\
\text { pertanggungjawaban } \\
\text { pidana perampasan } \\
\text { aset hasil tindak } \\
\text { pidana korupsi yang } \\
\text { sesuai dengan } \\
\text { pemikirankeadilan }\end{array}$ & $\begin{array}{l}\text { 1. TeoriTanggung Jawab } \\
\text { Hukum Desert Theory } \\
\text { (Andrew Von Hirsch } \\
\text { dan Andrew } \\
\text { Asworth)proporsionali } \\
\text { tas dalam pemidanaan } \\
\text { 2. Teorikedilan (John } \\
\text { Rawls); hak dan } \\
\text { kesempatan yang } \\
\text { sama atas kebebasan } \\
\text { dasaryang paling luas, } \\
\text { mampumengatur } \\
\text { kembalikesenjangan } \\
\text { sosial ekonomi yang } \\
\text { terjadi }\end{array}$ & $\begin{array}{l}\text { 1. Penelitian Normatif } \\
\text { (library reseach), } \\
\text { Statute Approach } \\
\text { 2. Pendekatan Analytical } \\
\text { \&Conseptual } \\
\text { Approarch dan } \\
\text { Comparatif } \\
\text { Methode } \\
\text { 3. Pengumpulan bahan hk } \\
\text { Dokumentatif \& } \\
\text { Snowball } \\
\text { 4. Analisa } \\
\text { deskriptif, Evalutatif, } \\
\text { argument atif }\end{array}$ \\
\hline \multicolumn{4}{|c|}{ PEMBAHASAN } \\
\hline \multicolumn{2}{|c|}{$\begin{array}{l}\text { PEMBAHASAN RUMUSAN MASALAH 1 } \\
\text { Konstruksi Hukum Pelaksanaan Perampasan Harta hasil tindak } \\
\text { pidana korupsi }\end{array}$} & \multicolumn{2}{|c|}{$\begin{array}{c}\text { PEMBAHASAN RUMUSAN MASALAH } 2 \\
\text { Bentuk konstruksi hukum yang sesuai dengan paradigma keadilar } \\
\text { Restoratif }\end{array}$} \\
\hline \multicolumn{2}{|c|}{$\begin{array}{c}\text { SIMPULAN } \\
\text { Konstruksi Hukum Perampasan Aset banyak Kelemahan } \\
\text { Konstruksi hukum kedepan sesuai dengan pemikiran restoratif }\end{array}$} & $\begin{array}{l}\text { Melakukan Peubahan KU } \\
\text { Menyusun Uu tent angp }\end{array}$ & $\begin{array}{l}\text { Aap tindak pidana tambahan } \\
\text { an harta hasil tindakpidana }\end{array}$ \\
\hline
\end{tabular}

\section{PEMBAHASAN}

\section{Konstruksi Hukum Pertanggungjawaban Pidana Perampasan Aset Hasil Tindak Pidana Korupsi di Indonesia saat ini}

Masalah perampasan aset hasil tindak pidana dan instrumen tindak pidana belum menjadi bagian penting dalam sistim hukum pidana di Indonesia ${ }^{21}$. Terbukti dengan menempatkan perampasan hanya sebagai pidana tambahan dan belum ada Peraturan perundang undangan yang khusus mengatur terkait dengan masalah perampasan aset hasil tindak pidana, perampasan harta diatur dalam KUHP pasal 10 huruf b angka 2, penerapan pasal ini hanya dapat dilakukan mengikuti pidana pokok yang diputuskan. Pidana tambahan tersebut bersifat fakultatif dimana hakim memiliki kebebasan untuk menggunakan atau tidak menggunakan pemidanaan tersebut ${ }^{22}$.

${ }^{21}$ Ramelan dkk. 2012, Laporan Akhir Naskah Akademik Rancangan Undang-Undang Tentang Perampasan Aset Tindak Pidana, Pusat Perencanaan Pembangunan Hukum Nasional, Badan pembinaan hukum nasional, Kementrian Hukum Dan Hak Asasi Manusia, Jakarta. h 1.

22 Jan Remmelink, 2003, Hukum Pidana, Komentar atas Pasal-Pasal Terpenting dari Kitab Undang-Undang Hukum Pidana Belanda dan Padanannya dalam Kitab Undang-Undang Hukum Pidana Indonesia, PT. Gramedia Pustaka Utama, Jakarta. h 490. 
Undang-undang No 31 Tahun 1999 tentang tindak pidana korupsi sebagaimana telah diubah dengan Undang-undang No 20 Tahun 2001 (UU PTPK) memberikan ancaman bagi pelaku tindak pidana korupsi berupa pidana penjara, pidana denda, dan pembayaran uang pengganti. Dapat dilakukan perampasan terhadap harta/aset terpidana apabila uang pengganti tidak dibayar oleh terpidana. Sedangkan pidana denda yang tidak dibayarkan oleh terpidana akan dikenakan hukuman kurungan sebagai pengganti denda. Selain ketiga sanksi tersebut, UU PTPK juga mengatur tentang dimungkinkannya melakukan perampasan aset hasil tindak pidana korupsi sebagaimana diatur dalam pasal 18 ayat (1) huruf a UU PTPK yang pada prinsipnya dapat dilakukan terhadap seluruh barang baik bergerak maupun tidak, berwujud dan tidak berwujud dari hasil tindak pidana korupsi.

Berkenaan dengan perampasan aset, sebagai upaya pengembalian kerugian Negara, di dalam UU PTPK dapat dilakukan dengan dua instrument yaitu instrument hukum Pidana dan instrument hukum Perdata.

\section{Perampasan Aset Hasil Tindak Pidana Korupsi dengan Instrumen} Pidana.

Perampasan terhadap aset hasil tindak pidana korupsi yang dilakukan melalui instrumen hukum pidana, diawali dengan melakukan penyitaan oleh penyidik terhadap harta terdakwa, yang selanjutnya penuntut umum harus dapat membuktikan kesalahan terdakwa telah melakukan tindak pidana korupsi, kemudian aset yang telah disita dimasukkan dalam tuntutan di rampas untuk negara sebagai pengembalian atas kerugian Negara melalui putusan hakim yang telah berkekuatan hukum tetap. Penyitaan aset para pelaku korupsi baik yang sudah jatuh ke tangan pihak ketiga merupakan langkah antisipatif yang bertujuan untuk menyelamatkan atau mencegah larinya harta kekayaan sebagaimana ditur dalam ketentuan umum Perja-013/A/JA/06/2014 tentang Pemulihan Aset.

Bahwa pada dasarnya prampasan aset hasil tindak pidana korupsi sangat tergantung dari kemampuan penuntut umum membuktikan kesalahan terdakwa dalam persidangan sekaligus pula membuktikan bahwa aset yang disita dan didakwakan merupakan hasil tindak pidana 
korupsi. Konsep yang demikian ini dinamakan perampasan aset berdasarkan kesalahan terdakwa (conviction base asset forfeiture) ${ }^{23}$.

Konsep conviction base asset forfeiture dapat ditemukan dalam pasal 39 dan pasal 46 ayat (2) KUHAP yang memberi batasan terhadap aset apa saja yang dapat disita. Selanjutnya, benda atau aset yang telah disita tersebut akan dirampas untuk negara jika ternyata terbukti merupakan hasil dari tindak pidana korupsi sebagaimana dimaksud dalam pasal 46 ayat (2) KUHAP.

Pada pasal 38 ayat (2) UU PTPK tersurat juga dasar hukum dari perampasan aset, yaitu apabila terdakwa tidak dapat membuktikan bahwa harta benda yang diperoleh bukan berasal dari tindak pidana korupsi, maka hakim berwenang memutuskan seluruh atau sebagian harta benda tersebut dirampas untuk Negara.

Namun demikian UU PTPK memiliki kelemahan, yakni jika melalui jalur tuntutan pidana seperti yang diuraikan diatas, upaya untuk merampas aset hasil tindak pidana hanya dapat dilaksanakan jika pelaku kejahatan oleh pengadilan telah dinyatakan terbukti secara sah dan meyakinkan bersalah melakukan tindak pidana korupsi dan telah terjadi kerugian Negara. Kesulitan yang sering terjadi adalah tidak ditemukannya alat bukti yang cukup dan aset yang sudah menghilang atau dipindah tangankan baik di dalam maupun pindah ke luar negeri.

\section{Perampasan Aset Hasil Tindak Pidana Korupsi dengan Instrumen Gugatan Perdata.}

Perampasan terhadap harta hasil tindak pidana korupsi melalui jalur perdata dalam UU PTPK hanya merupakan jalan alternatif semata, dilakukan ketika jalur pidana tidak dapat dilakukan karena alasan undangundang yaitu tersangka/terdakwa meninggal dunia, karena meninggalnya tersangka/terdakwa menghilangkan kewenangan menuntut (pasal 77 KUHP).

Perampasan dan pengembalian aset hasil tindak pidana korupsi yang dilakukan melalui jalur keperdataan didasarkan atas pasal 31 UU PTPK yang menentukan bahwa dalam hal penyidik menemukan dan

23 Mohamad Yusuf, 2013, Merampas Aset Koruptor , Solusi Pemberantasan Korupsi di Indonesia, PT. Kompas Media Nusantara, Jakarta, h. 162. 
berpendapat bahwa satu atau lebih unsur tindak pidana korupsi tidak terdapat cukup bukti, sedangkan secara nyata telah ada kerugian keuangan negara, penyidik segera menyerahkan berkas perkara hasil penyidikan tersebut kepada pengacara negara untuk dilakukan gugatan perdata atau diserahkan kepada instansi yang dirugikan untuk mengajukan gugatan, demikian halnya dilakukan sesuai pasal 31 ayat (2) terhadap perkara tindak pidana korupsi yang diputus bebas. Pasal 33 dalam hal tersangka meninggal dunia saat penyidikan, meninggal pada saat perkaranya sedang tahap penyidikan diketahui secara nyata telah ada kerugian Negara, Pasal 34 meninggal pada saat pemeriksaan sidang Pengadilan. Pasal $38 \mathrm{C}$ menetapkan apabila setelah putusan Pengadilan memperoleh kekuatan hukum tetap, diketahui masih terdapat harta benda milik terpidana yang diduga atau patut diduga juga berasal dari tindak pidana korupsi yang belum dikenakan perampasan untuk negara sebagaimana dimaksud dalam pasal 38 B ayat (2) maka negara dapat melakukan gugatan perdata terhadap terpidana atau ahli warisnya .

Dari uraian diatas, penulis berpendapat bahwa pertanggung jawaban pidana yang dilakukan berdasarkan atas KUHP dan UU PTPK walaupun sudah diatur soal perampasan aset hasil tindak pidana korupsi, namun tetap saja perampasan tersebut sebagai pidana tambahan, dan pelaksanaannya mengacu pada isi putusan hakim yang telah inkrah. Sedangkan instrumen perdata hanya sebagai alternatif saja yang hingga saat ini sepengetahuan penulis tidak pernah dilakukan. Keadaan inilah yang menghambat efektifitas dari upaya pengembalian kerugian negara akibat tindak pidana korupsi yang mencederai rasa keadilan Masyarakat.

Masyarakat sangat terganggu dengan perilaku koruptif para koruptor, yang menghambat terwujudnya kesejahteraan masyarakat. Penulis berpendapat bahwa pemidanaan perampasan harta hasil tindak pidana korupsi harus selalu diterapkan pada setiap penyelesaian tindak pidana korupsi dan mesti didukung dengan instrumen hukum yang jelas dan berkepastian agar dapat digunakan untuk merampas harta pelaku tindak pidana korupsi sehingga prinsip keadilan sosial bagi masyarakat dapat tercapai.

Jhon Rawls, menyatakan keadilan sebagai fairness bahwa tidak adil bilamana sebagian orang harus kekurangan, agar orang lain bisa 
menikmati kemakmuran ${ }^{24}$. Koruptor hanya mementingkan kepentingannya sendiri merupakan bentuk dari ketidak setaraan dalam penerapan hak dan kewajiban dan kondisi ini tidak menunjukkan keberpihakan pada masyarakat yang paling tidak beruntung oleh karenanya Negara harus hadir dalam menyelesaikan kasus korupsi melalui penerapan undangundang yang dapat memberikan rasa keadilan bagi masyarakat. KUHP dan UU PTPK tidak efektif mengembalian kerugian negara akibat tindak pidana korupsi, terbukti dari penelitian yang dilakukan ICW di tahun 2015 bahwa kerugian negara yang berhasil dikembalikan akibat tindak pidana korupsi baru 10 (sepuluh) persen dari jumlah kerugian yang terjadi. ${ }^{25}$ Untuk itu perlu melakukan upaya-upaya khususnya yang berhubungan dengan pembaharuan instrumen hukum baik yang sesuai dengan perkembangan / kebutuhan masyarakat secara nasional, maupun sesuai dengan perkembangan dunia internasional guna mendorong penegakan hukum yang lebih efektif tanpa meninggalkan pembangunan struktur hukum dan budaya hukum masyarakat.

Tahun 2003 lahirlah United Nations Convention against corruption (UNCAC) yang melengkapi dan mengatur mengenai bentuk-bentuk korupsi yang belum dicakup oleh instrumen-instrumen internasional sebelumnya ${ }^{26}$. UNCAC mengikat setiap anggota negara PBB yang telah meratifikasi dan dalam penerapannya akan berimplikasi terhadap peraturan perundangundangan yang berlaku di negara bersangkutan. Dalam hubungannya dengan perampasan aset hasil tindak pidana korupsi, UNCAC memberikan dasar hukum untuk melakukan penyitaan dan pengambilalihan aset dapat dilakukan melalui gugatan in rem atau gugatan terhadap aset yang diduga berasal, berkaitan atau merupakan hasil kejahatan atau yang dikenal

24John Rawls, 2011, Teori Keadilan, Dasar-dasar filsafat politik untuk mewujudkan kesejahteraan sosial dalam Negara. Terjemahan dari judul asli $A$ Theory of justice, Penerbit Pustaka Pelajar, Yogyakarta, h.13-16.

25 Adhitya Himawan \& NikolausTolen, 2015, KPK, Kejagung, \& Polri Selamatkan Uang Negara Rp3 Triliun di 2015 http://www.suara.com/news/2016/02/24/192347/kpk-kejagung-polri-selamatkanuang-negara-rp3-triliun-di-2015550ab527a33311cf1c2e39b diakses pada tanggal 4 Juli 2018.

\footnotetext{
${ }^{26}$ Mohamad Yusuf, Op.cit. h. 81
} 
dengan non-conviction base aset forfeiture (NCB aset forfeiture $)^{27} . N C B$ aset forfeiture tidak memerlukan pembuktian bahwa telah terjadi kerugian negara dan atau putusan atas kesalahan yang telah berkekuatan hukum seperti pada UU PTPK, Sebaliknya NCB mengadopsi prinsip pembuktian terbalik dimana pihak yang merasa keberatanlah yang membuktikan bahwa aset yang digugat tidak mempunyai hubungan dengan korupsi ${ }^{28}$. Pembuktian terbalik disini dimaksudkan juga bahwa pemerintah cukup mempunyai bukti awal bahwa aset yang akan diambil adalah hasil, berhubungan atau digunakan dari tindak kejahatan.

Filipina adalah salah satu Negara yang telah memperkenalkan penggunaan NCB Asset Forfeirture untuk mengejar aset tindak pidana, walaupun merupakan metode baru, namun masyarakat menerimanya sebagai instrumen hukum yang sangat baik dan penting dalam memerangi korupsi dan pencucian uang ${ }^{29}$. Penerapan NCB aset forfeiture menjadi suatu alternatif yang baik apabila jalur pidana tidak berhasil, dan dalam prakteknya prosedur $N C B$ dinilai lebih efektif mengembalikan aset-aset yang dicuri namun demikian di Indonesia NCB aset forfeiture tidak dapat diterapkan karena belum diatur dalam Undang-undang sebagaimana asas yang dianut dalam KUHP kita yaitu asas legalitas.

Diperlukan kebijakan formulasi hukum yang dapat memberikan efek jera secara efektif sekaligus juga pengembalian kerugian negara. Kondisi itulah yang menjadi alasan perlunya melakukan pembaharuan Hukum Pidana di Indonesia, namun kenyataannya draf Undang Undang tentang hukum pidana Indonesia yang sudah dibuat sejak tahun 1964 dan telah mengalami beberapa kali perubahan konsep dan telah pula masuk dalam prolegnas di DPR, hingga saat ini belum dapat terwujud.

Bahwa terdapat beberapa kendala dalam upaya pengembalian kerugian keuangan negara melalui perampasan aset yaitu: (1).Konstruksi sistem hukum pidana di Indonesia belum menempatkan penyitaan dan perampasan hasil dan instrumen tindak pidana sebagai bagian penting dari upaya menekan tingkat kejahatan di Indonesia. (2). Dalam perkembangan terakhir di dunia internasional, penyitaan dan perampasan hasil dan

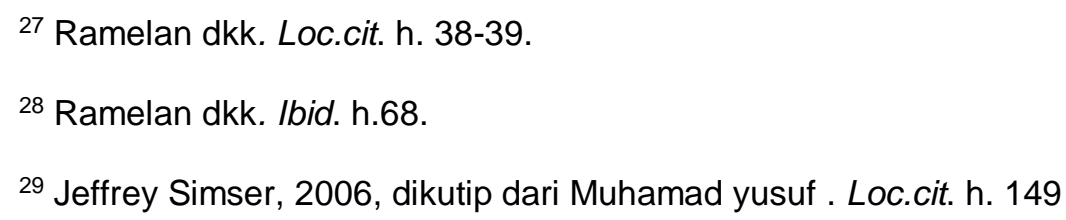


instrumen tindak pidana menjadi bagian penting dari upaya menekan tingkat kejahatan, seperti yang tercantum dalam UNTOC, UNCAC, yang keduanya telah diratifikasi oleh Indonesia, namun Indonesia belum memiliki Peraturan Perundang-undangan yang sejalan dengan perampasan aset berdasarkan dua konvensi internasional tersebut. (3).Peraturan Perundangundangan yang ada saat ini dinilai belum secara komprehensif dan rinci mengatur tentang perampasan aset yang terkait dengan tindak pidana, dan masih memiliki banyak kekurangan ${ }^{30}$.

Berdasarkan uraian di atas, serta memperhatikan perkembangan hukum pidana internasional, konsekuensi dari ratifikasi yang dilakukan oleh Pemerintah Indonesia, maka pemerintah bersama-sama lembaga legislatif harus segera merumuskan ketentuan-ketentuan yang belum diatur dalam peraturan perundang-undangan Indonesia dan bila sudah ada aturannya dalam peraturan perundang-undangan Indonesia, maka perlu disesuaikan dengan hukum pidana internasional dengan perluasan, penambahan dan penyesuaian terhadap ketentuan-ketentuan hukum yang berlaku saat ini. Penulis melihat adanya kebutuhan untuk merekonstruksi sistem Hukum Pidana di Indonesia dengan mengatur mengenai penyitaan dan perampasan hasil dan instrumen tindak pidana di dalam suatu Undangundang yang komprehensif juga harus terintegrasi agar mampu memberikan arah terhadap tujuan hukum yang dicita-citakan yaitu adanya kepastian hukum, keadilan dan kemanfaatan . Rekonstruksi Hukum Pidana Indonesia harus berpegang teguh pada Pancasila sebagai landasan filosofis seluruh Peraturan Perundangan yang ada untuk dapat memelihara dan mencapai ketertiban serta pemulihan hubungan antara pelaku, korban dan masyarakat sebagai wujud keadilan restoratif. Kondisi ini sesuai dengan perkembangan politik Hukum Pidana di berbagai Negara yang sejak pertengahan abad ke 20 telah beralih dari pendekatan retributive kepada pendekatan restorative. Penulis sependapat dengan apa yang disampaikan oleh Romli Atmasasmita bahwa pemidanaan dengan pendekatan restoratif yaitu dengan melakukan pengembalian asset hasil tindak pidana korupsi termasuk mekanisme penyitaan bertujuan memulihkan keadaan yang bermasalah atau mengalami ketidak seimbangan menjadi tidak bermasalah atau mencapai harmoni dalam

${ }^{30}$ Ramelan dkk, Loc.ci. h. $18-20$ 
kehidupan masyarakat atau dapat memberikan kemaslahatan bagi Negara dan Masyarakat ${ }^{31}$. Penulis berpendapat bahwa politik hukum perampasan harta kedepan harus mengadopsi pemikiran restorative justice yaitu mengembalikan keseimbangan dengan mewajibkan pelaku tindak pidana korupsi untuk melakukan pengembalian harta hasil tindak pidana korupsi. Untuk itu Negara harus segera menetapkan peraturan perundangundangan sebagai landasan untuk melaksanakan perampasan harta hasil tindak pidana korupsi demi mewujudkan keadilan, kemanfaatan dan kepastian hukum sesuai dengan teori tujuan hukum yang disampaikan oleh Gustav Radbruch.

Masih tingginya tingkat korupsi di Indonesia tentunya menjadikan kajian dari pihak berwenang untuk mengubah orientasi penanganan tindak pidana korupsi yaitu dari pendekatan follow the suspect (mencari,menangkap dan memenjarakan pelaku) menjadi follow the money, pengabungan kedua pendekatan tersebut akan menjadikan pencegahan dan pemberantasan tindak pidana korupsi semakin efektif ${ }^{32}$.

Perkembangan hukum di dunia internasional dalam hubungannnya dengan korupsi sudah mengarah kepada pembangunan instrumen hukum yang memberikan ruang kepada penegak hukum untuk melakukan perampasan harta hasil tindak pidana korupsi untuk mengembalikan kerugian negara yang timbul akibat tindak pidana korupsi yang merupakan implementasi dari keadilan restotarif, sekaligus juga sebagai upaya dalam memberikan rasa keadilan masyarakat yang bermuara pada percepatan capaian kesejahteraan masyarakat untuk mewujudkan tujuan Negara Indonesia sebagai Negara hukum kesejahteraan .

Sistem pemidanaan yang tercantum dalam pasal $10 \mathrm{KUHAP}$ pada dasarnya masih menganut paradigma retributive, yaitu pemidanaan dengan memberikan balasan yang setimpal atas kejahatan yang dilakukan oleh pelaku ternyata belum mampu memulihkan dan penderitaan yang dialami korban. Walaupun pelaku telah diputus bersalah dan mendapatkan hukuman, namun kondisi korban tidak dapat kembali seperti semula. Kondisi ini memunculkan gagasan baru tentang sistem pemidanaan yang

31 Romli Atmasasmita, 2011, Sistem Peradilan Pidana, Perspektif Ekstensialisme dan Abolisionisme, Bina Cipta, Bandung. h.75.

${ }^{32}$ Muhamad Yusuf, Op.cit. h. 223. 
berorientasi pada pemulihan kerugian dan penderitaan yang dialami korban yang dikenal dengan pendekatan restorative justice.

Keadilan restoratif sebagai salah satu bentuk pertanggungjawaban pidana yang berorientasi pada pengembalian kerugian dan mengembalikan seperti sediakala sebelum terjadinya tindak pidana, merupakan pemikiran yang harus ditanamkan pada penegak hukum khususnya tindak pidana korupsi. Welgrave mengemukakan bahwa teori keadilan restoratif adalah setiap perbuatan yang berorientasi pada penegakan keadilan dengan memperbaiki kerugian yang diakibatkan dari tindak pidana ${ }^{33}$. Bila dikaitkan dengan pengembalian aset dalam tindak pidana korupsi, dalam rangkaian tindakan penelusuran, pembekuan, penyitaan, perampasan dan akhinya tahap pengembalian aset Negara yang dikorupsi adalah sejalan dengan konsep keadilan restoratif yang mengutamakan perbaikan dan pengembalian kerugian yang diakibatkan oleh tindak pidana.

Tindak pidana korupsi merupakan tindakan mengambil kekayaan Negara secara melawan hukum, sehingga Negara kehilangan kemampuan untuk melaksanakan kewajiban dan tanggung jawab untuk mensejahterakan rakyatnya akibatnya rakyat kehilangan hak-hak dasar untuk hidup sejahtera. Tentu kondisi ini sangat bertentangan dengan teori keadilan yang dikemukakan oleh Jhon Rawls, yang mengisyaratkan bahwa sebagai mahluk ansali sesuai kodratnya manusia harus memiliki hak-hak dasar yang sama atas kesejahteraan yang diupayakan oleh negaranya. Oleh karenanya pertanggungjawaban pelaku tindak pidana korupsi sangat tidak adil bila pemidanaannya hanya sebatas apa yang diatur dalam undang-undang, yaitu dengan penjatuhan hukuman penjara dan penjatuhan denda, melainkan juga bertanggungjawab atas segala kerugian negara yang disebabkan olehnya dan memulihkan keuangan negara yang terpuruk atas tindak pidana korupsi.

Keadilan restoratif menawarkan pemikiran yang matang mengenai usaha apa saja yang harus ditempuh untuk mengembalikan keseimbangan dari suatu masyarakat atau negara akibat terjadinya tindak pidana. Restorative justice memahami tindak kejahatan tidak semata-mata sebagai pelanggaran terhadap sebuah entitas abstrak yang bernama Negara, melainkan lebih sebagai pelanggaran terhadap keadilan yang berlaku di

${ }^{33}$ Purwaning M. Yanuar. Loc.cit. h.90. 
masyarakat dan hubungan-hubungan sosial dimana titik tekan penyelesaiannya tidak diarahkan sekedar menghukum pelaku kejahatan karena melanggar hukum Negara, melainkan pada upaya-upaya untuk memulihkan hubungann-hubungan sosial masyarakat yang rusak akibat tindak kejahatan ${ }^{34}$. Perbedaan mendasar antara pendekatan restoratif dengan hukum formal terletak dari cara keduanya melihat tindak pidana. Seperti yang dikemukakan oleh Daniel dan Karen, Bila pendekatan pertama melihat peristiwa pelanggaran sebagai sesuatu yang harus dipertanggungjawabkan , terfokus pada subyek pelakunya maka pendekatan kedua melihatnya sebagai kondisi yang harus dipulihkan dalam rangka memperbaiki hubungan-hubungan. ${ }^{35}$ Pernyataan ini senada dengan apa yang telah disampaikan oleh Jenderal (Pol) Drs. Timur Pradopo dalam sambutannya dalam buku merampas aset koruptor bahwa pentingnya perubahan orientasi penanganan tindak pidana korupsi, yaitu dari pendekatan follow the suspect (menangkap dan memidanakan pelaku kejahatan) menjadi follow the money (menelusuri aliran dana) dalam rangka perampasan aset tindak pidana. Penggabungan kedua pendekatan tersebut, diyakini akan semakin meningkatkan efektifitas pemberantasan tindak pidana korupsi di Indonesia.

Dalam hubungannya dengan pengaturan perampasan harta hasil tindak pidana korupsi, sebagai wujud dari pelaksanaan keadilan restoratif, Penulis berpendapat bahwa Substansi hukum kita saat ini belum cukup memadai dan memiliki kelemahan dintaranya adalah pengaturan perampasan dalam KUHP, KUHAP maupun diatur secara khusus dalam berbagai Undang-undang menunjukkan ketidakharmonisan dan Undangundang khusus masih berlaku secara sektoral dalam memaknai aset yang dirampas dengan ruang lingkup yang berbeda. Kemudian Non Conviction Base Asset (NCB) hanya digunakan sebagai proses awal penanganan tindak pidana, yang kemudian dilanjutkan dalam proses peradilan sampai ada putusan pengadilan dan terakhir Perampasan aset menunggu putusan Hakim yang Inkrah.

${ }^{34}$ Afthonul Afif , 2015, Pemaafan, Rekonsiliasi Dan Restorative Justice, Diskursus Perihal Pelanggaran Di Masa Lalu Dan Upaya-Upaya Melampauinya. Pustaka pelajar, Yogyakarta. h. 325-329.

$$
35 \text { Ibid h.345. }
$$




\section{PENUTUP}

Dari apa yang telah diuraikan dalam penelitian ini, maka penulis mengambil kesimpulan dan saran sebagai berikut :

\section{A. Simpulan}

1. Konstruksi hukum yang berkaitan dengan perampasan aset hasil tindak pidana korupsi selama ini berdasar pada KUHP dan UU PTPK masih bersifat retributif sedangkan Pertangungjawaban pidana perampasan aset pelaku kejahatan hanya sebagai pidana tambahan bersifat alternatif dan komplementer tidak mendukung upaya penegakan hukum yang berkeadilan

2. Harus ada perubahan paradigma kepada sistem pemidanaan yang berorientasi pada pemulihan kerugian dan penderitaan yang dialami korban untuk mengembalikan keseimbangan akibat tindak pidana korupsi yang dikenal dengan restorative justice.

\section{B. Saran}

1. Legislatif bersama sama dengan eksekutif sebagai penyusun kebijakan peraturan perundang undangan melakukan kajian untuk segera melakukan perubahan mendasar terhadap KUHP khususnya Pasal 10 huruf $b$ dengan menempatkan perampasan harta yang berhubungan dengan tindak pidana menjadi pidana pokok.

2. Indonsia telah meratifikasi UNCAC 2003, maka sudah menjadi keharusan bagi negara untuk menyesuaikan UU PTPK dengan ketntuan dalam UNCAC dan selanjutnya menyusun UU tentang perampasan aset hasil tindak pidana sebagai landasan penerapan perampasan aset hasil tindak pidana.

\section{DAFTAR PUSTAKA}

\section{Buku:}

Afthonul, A., 2015. Pemaafan, rekonsiliasi dan restorative justice, diskursus perihal pelanggaran di masa lalu dan upaya-upaya melampauinya. Pustaka Pelajar, Yogyakarta.

Hotmaulana, H.R.,201,3 Penanggulangan Kejahatan Korporasi melalui pendekatan Restoratif suatu terobosan hukum, edisi 1, Sinar grafika, Jakarta. 
Maheka, A., 2014, Mengenal dan Memberantas Korupsi,Komisi Pemberantasan Korupsi,Jakarta.

Pasek, I.M.D., 2016, Metode Penelitian Hukum Normatif Dalam Justifikasi Teori Hukum, Cetakan ke-1. Prenada Media Group, Jakarta.

Romli, Atmasasmita, 1996, Sistem Peradilan Pidana, Perspektif Ekstensialisme dan Abolisionisme, Bina Cipta,Bandung.

Ramelan dkk., 2012, Laporan Akhir Naskah akademik Rancangan Undangundang tentang perampasan aset tindak pidana. Pusat perencanaan pembangunan hukum nasional, Badan pembinaan hukum nasional. Jakarta: kementrian hukum dan hak asasi manusia.

Rawls, J., 2011, Teori Keadilan, Dasar-dasar filsafat politik untuk mewujudkan kesejahteraan sosial dalam Negara. Terjemahan dari judul asli $A$ Theory of justice, : Pustaka Pelajar,Yogyakarta.

Remmelink, J. 2003, Hukum Pidana, Komentar atas Pasal-Pasal Terpenting dari Kitab Undang-Undang Hukum Pidana Belanda dan Padanannya dalam Kitab Undang-Undang Hukum Pidana Indonesia, PT. Gramedia Pustaka Utama, Jakarta.

Salim HS. H., and Nurbani Erlies Septiana, 2015, Penerapan Teori Hukum Pada Penelitian Disertasi Dan Tesis ( buku kedua), Cetakan ke-2, PT. Raja Grafindo Persada, Jakarta.

Saleh, R. 1990, Perbuatan Pidana dan Pertanggungjawaban Pidana. Aksara Baru,Jakarta.

Soekanto, S., and Mamudji Sri,2011, Penelitian Hukum Normatif, Rajawali Pers, Jakarta.

Suted, A.,2009, Aspek Hukum Barang dan Jasa dan Berbagai Permasalahannya, Sinar Grafika, Jakarta.

Tanya, Bernard L dkk., 2013, Teori Hukum strategi tertib manusia lintas ruang dan generasi, cetakan IV edisi revisi, Genta Publishing, Jogyakarta.

Waluyo, B.,2016, Penegakan hukum di Indonesia, Sinar Grafika, Jakarta.

Yanuar, P.M.,2007, Pengembalian Aset Hasil Korupsi, PT Alumni, Bandung.

Yusuf, M.,2013, Merampas Aset Koruptor, Solusi Pemberantasan Korupsi di Indonesia, : PT. Kompas Media Nusantara,Jakarta. 
Yulianto, I., 2016, Kejahatan percobaan Pembunuhan Dalam hukum Pidana, Jurnal IImiah Fenomena, XIV (2), November 2016. https://Jurnal .unars.ac.id

\section{Peraturan Perundang-Undangan}

Undang Undang Dasar Negara Republik Indonesia Tahun 1945.

Undang Undang Republik Indonesia No 1 Tahun 1946. Tentang Peraturan Hukum Pidana, Lembaran Negara no No. 127, tahun 1958.

Undang Undang Republik Indonesia No. 73 Tahun 1958. Tentang Menyatakan Berlakunya Undang-Undang No 1 Tahun 1947 Untuk Seluruh Wilayah Indonesia dan Mengubah UU Hukum Pidana, Lembaran Negara no No. 127, tahun 1958.

Undang-Undang Republik Indonesia Nomor 8 Tahun 1981 Tentang Hukum

Acara Pidana. Lembaran Negara no No.76 Tahun 1981.

Undang-Undang Republik Indonesia Nomor 31 tahun 1999 Tentang

Pemberantasan Tindak Pidana Korupsi . Lembaran Negara Republik Indonesia Nomor 387.

Undang-Indang Republik Indonsia Nomor 20 Tahun 2001 tentang

Perubahan Atas Undang-Undang Nomor 31 Tahun 1999 Tentang Pemberantasan Tindak Pidana Korupsi. Lembaran Negara Republik Indonesia Tahun 2001 Nomor 134.

\section{Artikel Internet:}

BBC Indonesia, 2017. Indek Persepsi Korupsi Indonesia Disebut Membaik tapi lamban, available at http://www.bbc.com/indonesia/indonesia$\underline{38734494}$ diunduh pada tanggal 23 Pebruari 2018

Himawan, A., and NikolausTolen, 2015, KPK, Kejagung, \& Polri Selamatkan Uang Negara Rp3 Triliun di 2015 Available Cited at: http://www.suara.com/news/2016/02/24/192347/kpk-kejagung-polriselamatkan-uang-negara-rp3-triliun-di-

2015550ab527a33311cf1c2e39b diunduh pada tanggal 4 Juli 2018. Ruli, 2016, Kerugian Negara Akibat Korupsi Rp31,077 Triliun. Available at : http://nasional.harianterbit.com/nasional/2016/02/24/57464/44/25/ICWTahun-2015- Kerugian- Negara-Akibat-Korupsi-Rp31077-Triliun. 
Diakses pada tanggal 16 Juli 2017.

Rolas, J. (2015)._Korupsi Merupakan Extra Ordinary Crime. Available at:

http://www.kompasiana.com/www.rolastampubolon.wordpress.com/korupsi-

merupakan-extra-ordinary-crime_552c09f76ea8341e2f8b4581

diakses pada tanggal 16 Juli 2017. 